\title{
Digestive enzymes in the ontogenetic stages of the southern king crab, Lithodes santolla
}

\begin{abstract}
The early ontogenetic stages of the sub-Antarctic king crab Lithodes santolla were analyzed for the presence and activities of a set of important digestive enzymes. The eggs and non-feeding larvae (zoea I-III, megalopa) showed high activities of esterases, phosphatases, and exopeptidases indicating the enzymatic ability to utilize endogeneous yolk reserves. SDS-PAGE showed a continuous decrease of proteins or proteids in the range of 59-81 kDa during ontogenetic development from the eggs through the zoeal stages to the first juvenile crab stage, CI. This reduction reflects the degradation of storage compounds during lecithotrophic larval development. Activities of the endopeptidases, trypsin and chymotrypsin, were low in eggs and larvae but increased significantly in the first juvenile crab stage. These enzymes typically facilitate the first steps of proteolysis in the extra-cellular spaces of the midgut gland and in
\end{abstract}

Communicated by O. Kinne, Oldendorf/Luhe

R. Saborowski $(\bowtie) \cdot K$. Anger

Biologische Anstalt Helgoland,

Foundation Alfred Wegener Institute for Polar

and Marine Research,

27498, Helgoland, Germany

S. Thatje

Alfred Wegener Institute for Polar and Marine Research,

Am Handelshafen 12, 27515, Bremerhaven, Germany

S. Thatje

National Oceanography Centre, Southampton, University of Southampton, European Way, SO14 3ZH, Southampton, UK

J. A. Calcagno

Facultad de Sciencias Exactas y Naturales,

Universidad Buenos Aires,

Conse jo Nacional de Investigaciones

Científicas y Técnicas, Intendante Güiraldes 2160,

Lab 64, 4to Piso, Pbab II, Cdad Universitaria,

C1428EHA, Buenos Aires, Argentina

G. A. Lovrich

Consejo Nacional de Investigaciones Científicas y Técnicas,

Centro Ausral de Investigaciones Científicas, CADIC, CC 92,

V9410BFD, Ushuaia, Tierra del Fuego, Argentina the stomach. Their scarcity indicates that the larvae of L. santolla are physiologically not prepared to digest external food. This ability seems to appear first in the CI stage. Extracts of juvenile midgut glands and the gastric fluids of adults showed high activities of a variety of digestive enzymes including phosphatases, carbohydrases, as well as endo- and exopeptidases. High activities of digestive enzymes in adults may compensate for scarce food supply and rate-limiting low temperatures in the predominantly sub-Antarctic habitats of L. santolla.

\section{Introduction}

Species of king crabs (Lithodidae) are common in high latitude regions, which are characterized by short periods of primary production and low temperatures during the summer (Dawson 1989). Under these conditions, planktonic larval stages may be constrained by food limitation during the short seasons of primary production, while low temperatures enforce a prolongation of the pelagic phase of development. As an evolutionary adaptation to such adverse trophic and thermal conditions, many benthic marine species have abbreviated their planktonic development by reducing the number of larval stages, and these show frequently a lecithotrophic, i.e. a food-independent mode of development (Thorson 1936, 1950; for recent discussion, see Anger 2001; Thatje et al. 2005).

Recent laboratory studies on the reproductive strategies of sub-Antarctic lithodid crabs showed that the demersal zoeal development from hatching to metamorphosis lasted at $6^{\circ} \mathrm{C}$ about 60 days in the false king crab, Paralomis granulosa, and 70 days in the southern king crab, Lithodes santolla. During the entire development from hatching to metamorphosis, the larvae of both species were never observed to accept food, nor were their developments accelerated when Artemia nauplii were offered as a live food (Calcagno et al. 2004). Additionally, the mandibles were in the zoeal stages 
morphologically poorly developed and apparently nonfunctional, suggesting that larvae are not able to capture, process, and ingest prey (McLaughlin et al. 2001, 2003). However, it remained uncertain when in ontogeny the internal digestive system of these lithodid crabs becomes functional, potentially enabling also their larval stages to digest matter from food.

The aim of the present work was to investigate the appearance of important digestive enzymes in different ontogenetic stages of the southern king crab, L. santolla. Particular interest was focussed on how the composition of digestive enzymes changes during development through successive larval, juvenile, and adult stages and at which stage larvae develop the potential to digest exogenous food. A semi-quantitative enzyme assay was used to screen a variety of digestive enzymes and compare their activities among stages. Selected endo- and exopeptidases may help to distinguish between extraand intracellular digestive processes.

\section{Material and methods}

Origin of animals and maintenance

The capture and maintenance of southern king crabs, L. santolla, was described in detail by Lovrich et al. (2003). In brief, ovigerous females were caught in April 2001 in the Beagle Channel and thereafter maintained at $6^{\circ} \mathrm{C}$ in the "Centro Austral de Investigaciones Cientificas" in Ushuaia, Argentina. In May 2001, the animals were shipped with RVs "Polarstern" and "Uthörn" to the Marine Biological Station Helgoland (Germany). On Helgoland, the crabs were kept separately in flowthrough aquaria. Maintenance of females and rearing of larvae were carried out at $6^{\circ} \mathrm{C}$, a salinity of 32 , and a 12:12-h light/dark cycle.

Freshly hatched larvae were collected from the overflow of the tanks and were subsequently maintained individually at $6^{\circ} \mathrm{C}$ in $100 \mathrm{ml}$ glass beakers filled with seawater. During September-November 2001, eggs and larvae from different stages (zoea I-III and megalopa) were taken from the cultures and frozen at $-80^{\circ} \mathrm{C}$ for enzymatic analysis. Juveniles were reared until August 2002. After killing the crabs by shock freezing at $-80^{\circ} \mathrm{C}$, the midgut glands were carefully dissected, weighed, and stored at $-80^{\circ} \mathrm{C}$ for enzymatic analysis.

\section{Preparation of extracts}

Extracts of eggs and larvae (5 each, 17-27 mg in total) were prepared in $500 \mu$ ldemineralized water (a. dem.) by homogenization with an ultrasonic cell disrupter (Branson Sonifier B12 equipped with a microtip) for three times $5 \mathrm{~s}$ while being cooled on ice. The homogenates were then centrifuged for $15 \mathrm{~min}$ at $15,000 \mathrm{~g}$ and $4^{\circ} \mathrm{C}$. The supernatants were transferred into new reaction cups. If lipids were not sufficiently separated, the centrifugation step was repeated before the extracts were used for subsequent enzyme assays.

Subsamples of midgut gland tissues $(20-70 \mathrm{mg})$ were weighed into reaction tubes and homogenized in $1 \mathrm{ml}$ of a. dem. as described above for larvae. Gastric fluid was drawn with a syringe and a Teflon tube from the stomach of four adult $L$. santolla. The fluid was immediately transferred into reaction tubes and centrifuged at $15,000 \mathrm{~g}$ for $10 \mathrm{~min}$. Aliquots of the supernatants were applied to enzyme assays or were frozen and stored at $-80^{\circ} \mathrm{C}$ until further analysis. Aqueous dilutions of 1:100 or 1:200 were used for enzyme assays and for electrophoresis.

The concentrations of soluble protein in the extracts were measured after Bradford (1976). The samples were first diluted $1: 10$ or $1: 20$ with $\mathrm{a}$. dem. and were then applied in triplicate, $20 \mu \mathrm{l}$ each, on microplates. Subsequently, $250 \mu \mathrm{l}$ of the dye reagent (BioRad 500-0006, diluted 1:5 with a. dem.) were added and the optical density was measured at $600 \mathrm{~nm}$ in a microplate reader. Standards of bovine serum albumin (BSA, $0-5 \mu \mathrm{g}$ per well) were run in parallel.

\section{Enzyme screening}

Samples were screened for a set of 19 enzymes with a semi-quantitative micromethod (ApiZym, bioMérieux, France). Each of the wells of the test strip was inoculated with $50 \mu \mathrm{l}$ of sample (enzyme extract) and incubated for $2 \mathrm{~h}$ at $30^{\circ} \mathrm{C}$. After addition of reagents Zym A and Zym B the color which developed in each well was determined visually and, according to the manufacturers instructions, the activity was ranked from "0" (no activity) to " 5 " (highest activity).

\section{Quantitative enzyme assays}

Total proteolytic activity was assayed with azocaseinNa-salt (Serva, 14391) as substrate. Two hundred microliters of phosphate buffer $\left(50 \mathrm{mmol} \mathrm{l}^{-1} \mathrm{NaH}_{2} \mathrm{PO}_{4}\right.$, $50 \mathrm{mmol} \mathrm{l}^{-1} \mathrm{Na}_{2} \mathrm{HPO}_{4}, 150 \mathrm{mmol} \mathrm{l}^{-1} \mathrm{NaCl}, \mathrm{pH}$ 6.8) and $20 \mu \mathrm{l}$ of sample were filled into $1.5 \mathrm{ml}$ reaction cups and incubated at $30^{\circ} \mathrm{C}$ for $5 \mathrm{~min}$ in a thermomixer (Eppendorf, model 5437). The reaction was initiated by addition of $100 \mu \mathrm{l}$ of azocasein solution $(1 \% \mathrm{w} / \mathrm{v}$ in phosphate buffer, $\mathrm{pH}$ 6.8). The mixture was incubated for $30 \mathrm{~min}$ at $30^{\circ} \mathrm{C}$ and then was stopped by the addition of $500 \mu \mathrm{l}$ of trichloroacetic acid (TCA, 20\% in demineralized water). Blanks were run in parallel in which the samples were added immediately after the reaction was terminated. The reaction cups were placed on ice for a few minutes and then were centrifuged for $10 \mathrm{~min}$ at $15,000 \mathrm{~g}$ and $4^{\circ} \mathrm{C}$. The absorption of the supernatant was measured in a spectrophotometer at $366 \mathrm{~nm}$. The activity was expressed as the change of absorption per time and protein weight units $\left(\Delta A_{366} \mathrm{~min}^{-1} \mathrm{~g}_{\mathrm{prt}}^{-1}\right)$. 
Trypsin activity was determined after Geiger and Fritz (1988) with the substrate $N^{\alpha}$-benzoyl-L-arginin-4nitroanilide-hydrochloride (L-BAPA, Merck 10754) as follows: $600 \mu \mathrm{l}$ Tris- $\mathrm{HCl}$ buffer, $\left(50 \mathrm{mmol} \mathrm{l}^{-1}, \mathrm{pH} 7.5\right)$ and $20 \mu \mathrm{l}$ of sample were incubated in a cuvette for 5 min at $30^{\circ} \mathrm{C}$. The reaction was started by the addition of $20 \mu \mathrm{l} \mathrm{L}$-BAPA $\left(13.9 \mathrm{mg} \mathrm{ml}^{-1}\right)$ dissolved in dimethylsulfoxide (DMSO). The substrate concentration in the reaction mixture was $1 \mathrm{mmol} \mathrm{l}^{-1}$. The reaction was continuously recorded at $405 \mathrm{~nm}$ for $5 \mathrm{~min}$. The activity

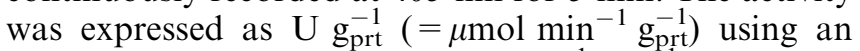
extinction coefficient of $10.21 \mathrm{mmol}^{-1} \mathrm{~cm}^{-1}$.

Chymotrypsin activity was measured according to Geiger (1988) with the substrate $N$-succinyl-ala-ala-prophe $p$-nitroanilide (SAAPPNA, Sigma S-7388). SAAPPNA was dissolved in DMSO $\left(20 \mathrm{mg} \mathrm{ml}^{-1}\right)$ and applied at a final concentration of $1 \mathrm{mmol}^{-1}$. The protocol was the same as described for trypsin and the same extinction coefficient was used.

Alanin-aminopeptidase (alanine arylamidase) activity was determined after Hafkenscheid (1988) with the substrate L-alanine- $p$-nitroanilide (Sigma, A-9325). The substrate was dissolved in DMSO $\left(78.6 \mathrm{mg} \mathrm{ml}^{-1}\right)$ and applied at a final concentration of $10 \mathrm{mmol} \mathrm{l}^{-1}$ in the reaction mixture. The activity was expressed as $\mathrm{U} \mathrm{g}_{\mathrm{prt}}^{-1}$ $\left(=\mu \mathrm{mol} \mathrm{min} \mathrm{min}^{-1} \mathrm{~g}_{\mathrm{prt}}^{-1}\right)$ using an extinction coefficient of $9.91 \mathrm{mmol}^{-1} \mathrm{~cm}^{-1}$.

SDS-PAGE and endopeptidase zymograms

Separation of proteins was performed by SDS-PAGE $(12 \%$ T, $2.7 \%$ C). Samples that were also used for enzyme measurements were mixed 1:2 with sample buffer (containing 4\% SDS) but were not heated. Ten microliters of sample were applied onto the gel. Electrophoresis was run in a water-cooled Hoefer-SE 250 device at $1-3^{\circ} \mathrm{C}$. Low weight proteins (SigmaMarker, M 3913) were used as molecular weight standards. Running conditions were $15 \mathrm{~mA}$ per gel at maximum $300 \mathrm{~V}$. After the run gels were stained with Coomassie brilliant blue.

Substrate-gel electrophoresis for endopeptidases was performed according to Garçia-Carreño et al. (1993). Samples were mixed with samples buffer containing $4 \%$
SDS but not heated and were separated by SDS-PAGE $(15 \% \mathrm{~T}, 3 \% \mathrm{C})$. After the run the gel was submerged in $100 \mathrm{ml}$ of ice-cold casein solution $\left(3 \%\right.$ in $100 \mathrm{mmol} \mathrm{l}^{-1}$ Tris- $\mathrm{HCl}, \mathrm{pH} 8.0$ ). The casein was allowed to penetrate into the gel for $30 \mathrm{~min}$ while being gently agitated on an orbital shaker. Thereafter, the incubation was continued at room temperature for another $60 \mathrm{~min}$. Finally, the gel was thoroughly washed with a. dem. and stained for protein with Coomassie brilliant blue. Bands of activity appeared pale on an otherwise blue-dyed background caused by undigested casein.

\section{Statistics}

Statistical analysis was carried out with the computer program SigmaStat 2.03 (SPSS Inc., Chicago, IL, USA). Data sets were analyzed by one-way ANOVA. Pairwise multiple comparisons were performed with the Tukey test. Results were presented in tables and figures as means \pm standard deviation. Statistically significant differences $(P<0.05)$ were indicated by different letters. Protein and activity bands on the electrophoresis gels were analyzed for molecular weight using the software package Quantity One (BioRad).

\section{Results}

Weight and protein amount

The average fresh weight (FW) of the eggs of L. santolla was $3.45 \pm 0.09 \mathrm{mg}$. The FW of the zoeal stages I-III and megalopae (ZI-ZIII/M) was significantly higher, ranging from 3.88 to $3.94 \mathrm{mg}$ (Table 1). In the first juvenile crab stage (CI) the FW exceeded significantly that of all previous stages $(5.10 \pm 0.33 \mathrm{mg})$.

The amount of water-soluble protein was lowest in the eggs $\left(225.6 \pm 19.0 \mu \mathrm{g}\right.$ ind $\left.^{-1}\right)$ and highest in the ZI stage $\left(468.2 \pm 35.7 \mu \mathrm{g}\right.$ ind $\left.^{-1}\right)$. The amount of soluble protein decreased continuously from the ZI to the CI (Table 1), where it did not differ significantly from the protein amount of the eggs.

Table 1 Weights and amounts of water extractable protein of eggs, larvae, and CI stages of L. santolla

\begin{tabular}{lllr}
\hline & Weight $\left(\mathrm{mg} \mathrm{ind}^{-1}\right)$ & Water soluble protein \\
\cline { 2 - 4 } & & $\left(\mu\right.$ ind $\left.^{-1}\right)$ & $(\%$ w/w) \\
\hline Eggs & $3.45 \pm 0.09^{\mathrm{a}}$ & $225.6 \pm 19.0^{\mathrm{a}}$ & $6.54 \pm 0.46^{\mathrm{a}}$ \\
Z I & $3.94 \pm 0.21^{\mathrm{b}}$ & $468.2 \pm 35.7^{\mathrm{b}}$ & $11.88 \pm 0.83^{\mathrm{b}}$ \\
Z II & $3.88 \pm 0.25^{\mathrm{b}}$ & $29.8 \pm 40.4^{\mathrm{b}}$ & $7.59 \pm 0.41^{\mathrm{b}}$ \\
Z III-M & $3.88 \pm 0.07^{\mathrm{b}}$ & $250.3 \pm 14.8^{\mathrm{a}, \mathrm{c}}$ & $4.93 \pm 0.44^{\mathrm{c}}$ \\
C I & $5.10 \pm 0.33^{\mathrm{c}}$ & & $2.76 \pm 0.61^{\mathrm{d}}$ \\
MGG juv & & & $2.56 \pm 1.43^{\mathrm{d}}$ \\
GF adult & & & \\
\hline
\end{tabular}

Different letters indicate significant statistical differences $(P<0.05)$

$M G G$ juv midgut gland extracts of juvenile crabs, $G F$ adult gastric fluid of adult crabs (means $\pm \mathrm{SD}, n=4-7$ ) 
Table 2 Carapace lenth (CL), fresh weight (FW), weight of the midgut gland (MGG) and the midgut gland index $(\%$ of total weight) of individual juveniles of $L$. santolla

\begin{tabular}{lllcl}
\hline Ind. & CL $(\mathrm{mm})$ & FW $(\mathrm{mg})$ & MGG juv (mg) & MGG index \\
\hline 1 & 10.7 & 315 & 19.6 & 6.22 \\
2 & 11.0 & 309 & 22.7 & 7.35 \\
3 & 14.7 & 864 & 44.9 & 5.20 \\
4 & 16.5 & 1180 & 69.5 & 5.89 \\
5 & 17.2 & 1428 & 106.3 & 7.44 \\
6 & 17.9 & 1471 & 94.9 & 6.45 \\
\hline
\end{tabular}

The share of water-soluble protein in the eggs amounted to $6.54 \pm 0.46 \% \mathrm{w} / \mathrm{w}$. It was significantly higher in the zoea and megalopa stages and decreased again in the first crab stage (Table 1). Extracts of juvenile midgut glands and the gastric fluid of adults showed the lowest amount of water-soluble protein (2.76 and $2.56 \% \mathrm{w} / \mathrm{w})$.

The FW of juveniles used for the study of digestive enzymes in the midgut glands ranged between 315 and $1,471 \mathrm{mg}$ (Table 2). The FW of the midgut glands varied from 19.6 to $106.3 \mathrm{mg}$. The $\mathrm{FW}$ of the midgut gland amounted on average to $6.4 \pm 0.9 \%$ of total body weight (MGG index).

Table 3 Semi-quantitative screening of enzyme activities from extracts of eggs, zoea I, midgut gland extracts of juveniles (MGG juv), and the gastric fluid of adult (GF adult) L. santolla

\begin{tabular}{|c|c|c|c|c|}
\hline Enzyme & Egg & Zoea 1 & $\begin{array}{l}\text { MGG } \\
\text { juv }\end{array}$ & $\begin{array}{l}\text { GF } \\
\text { adult }\end{array}$ \\
\hline Control & 0 & 0 & 0 & 0 \\
\hline $\begin{array}{l}\text { Enzymes with high activities } \\
\text { Phosphatase alkaline } \\
\text { Phosphatase acid } \\
\text { Naphtol-AS-bi-phosphohydrolase } \\
\text { Leucine arylamidase } \\
\text { Valine arylamidase } \\
\beta \text {-galactosidase } \\
\beta \text {-glucuronidase } \\
N \text {-acetyl- } \beta \text { glucosaminidase }\end{array}$ & $\begin{array}{l}4 \\
4 \\
3 \\
5 \\
5 \\
4 \\
4 \\
4\end{array}$ & $\begin{array}{l}5 \\
4 \\
4 \\
5 \\
5 \\
4 \\
4 \\
4\end{array}$ & $\begin{array}{l}5 \\
4 \\
4 \\
5 \\
4 \\
5 \\
4 \\
5\end{array}$ & $\begin{array}{l}5 \\
5 \\
5 \\
5 \\
5 \\
5 \\
3 \\
5\end{array}$ \\
\hline $\begin{array}{l}\text { Enzymes with low activities } \\
\text { Esterase (C4) } \\
\alpha \text {-fucosidase }\end{array}$ & $\begin{array}{l}2 \\
2\end{array}$ & $\begin{array}{l}3 \\
2\end{array}$ & $\begin{array}{l}1 \\
4\end{array}$ & $\begin{array}{l}3 \\
2\end{array}$ \\
\hline $\begin{array}{l}\text { Enzymes with increasing activities } \\
\text { Cysteine arylamidase } \\
\text { Trypsin } \\
\alpha \text {-glucosidase } \\
\beta \text {-glucosidase } \\
\alpha \text {-mannosidase }\end{array}$ & $\begin{array}{l}1 \\
0 \\
2 \\
1 \\
1\end{array}$ & $\begin{array}{l}2 \\
1 \\
2 \\
1 \\
1\end{array}$ & $\begin{array}{l}3 \\
4 \\
5 \\
2 \\
3\end{array}$ & $\begin{array}{l}3 \\
5 \\
5 \\
5 \\
5\end{array}$ \\
\hline $\begin{array}{l}\text { Enzymes with decreasing activities } \\
\text { Esterase lipase (C8) }\end{array}$ & 4 & 4 & 2 & 1 \\
\hline $\begin{array}{l}\text { No activities detected } \\
\text { Lipase (C14) } \\
\text { Chymotrypsin } \\
\alpha \text {-galactosidase }\end{array}$ & $\begin{array}{l}0 \\
0 \\
0\end{array}$ & $\begin{array}{l}0 \\
0 \\
0\end{array}$ & $\begin{array}{l}0 \\
0 \\
0\end{array}$ & $\begin{array}{l}0 \\
0 \\
0\end{array}$ \\
\hline
\end{tabular}

0 no activity, 5 highest activity
Enzyme screening

Phosphoesterases with a wide specificity such as alkaline and acid phosphatase showed in all samples highest activities (Table 3). The activity of naphtol-AS-Biphosphatase, however, was lower in eggs than in ZI stages and in juvenile midgut glands. Highest activities appeared in the gastric fluid of adult crabs. Similar to phosphoesterases, high activities of exopeptidases (leucine- and valine arylamidase), carbohydrases ( $\beta$-galactosidase, $n$-acetyl- $\beta$ glucoseaminidase, $\beta$-glucuronidase) were present in all samples. The activities of esterase (C4) and $\alpha$-fucosidase remained in all stages at an intermediate level. Enzymes with distinctly increasing activity between eggs and adult gastric fluid were cysteine arylamidase, trypsin, $\alpha$ - and $\beta$-glucosidase, and $\alpha$-mannosidase. A decrease of activity was evident only in esterase/lipase (C8). No activity was detected with the ApyZym assay for lipase (C14), chymotrypsin, and $\alpha$-galactosidase.

\section{Quantitative enzyme assays}

The activities of total proteinase as measured by azocasein digestion ranged in the eggs and in the larval stages between 10.8 and $18.4 \Delta A_{366} \mathrm{~min}^{-1} \mathrm{~g}_{\text {prt }}^{-1}$ (Fig. 1a). In the CI stage, activities increased significantly to $31.9 \Delta A_{366}$ $\min ^{-1} \mathrm{~g}_{\mathrm{prt}}^{-1}$. The trypsin activities (Fig. 1b) were low in eggs and larval stages (1.0-2.4 $\left.\mathrm{U} \mathrm{g} \mathrm{grt}_{\mathrm{prt}}^{-1}\right)$ but increased significantly in the CI (7.9 $\left.\mathrm{U} \mathrm{g} \mathrm{grt}_{\mathrm{pr}}^{-1}\right)$. The same pattern was evident for chymotrypsin (Fig. 1c). Here, activities ranged between 1.5 and $3.5 \mathrm{U} \mathrm{g}_{\mathrm{prt}}^{-1}$ and did not differ significantly between eggs and larval stages. In the CI, however, the activities were significantly higher than in all other stages $\left(10.1 \mathrm{U} \mathrm{g} \mathrm{grt}_{\mathrm{prt}}^{-1}\right)$. Different to trypsin and chymotrypsin, the activities of alanine-aminopeptidase were high already in the eggs and in ZI and ZII stages (Fig. 1d), ranging between 84.3 and $89.5 \mathrm{U} \mathrm{g} \mathrm{grt}_{\text {prt }}^{-1}$ In ZIII/megalopae, the activities further increased to $120.2 \mathrm{U} \mathrm{g}_{\mathrm{prt}}^{-1}$. In CI the average activity amounted to $140.6 \mathrm{U} \mathrm{g}_{\mathrm{prt}}^{-1}$. Enzyme activities in midgut gland extracts of juvenile and in the gastric fluids of adults were up to 40 times and up to 500 times, respectively, higher than in larval stages (Fig. 2ac). Only the activities of alanine-aminopetidase in the midgut gland extracts of juveniles remained at the same order of magnitude as in larval stages (Fig. 2d).

Ontogenetic changes in the ratio exopeptidase/endopeptidase

The ratios of activities of the exopeptidase alanine-aminopeptidases and the endopeptidase chymotrypsin changed continuously during the larval development (Fig. 3a). In the eggs, the activity of alanine-aminopeptidase was on average 35 times higher than that of chymotrypsin. This ratio increased in the ZI stage to 63 and then continuously decreased reaching a value of 13 in the CI stage. 
Fig. 1 Enzyme activities of developmental stages of L. santolla (means $\pm \mathrm{SD})$. $E$ eggs, $Z I$ zoea I, ZII zoea II, $Z I I I / M$ zoea III and megalopae, $C I$ crab I. Different letters indicate significant differences $(P<0.05, n=4-7)$
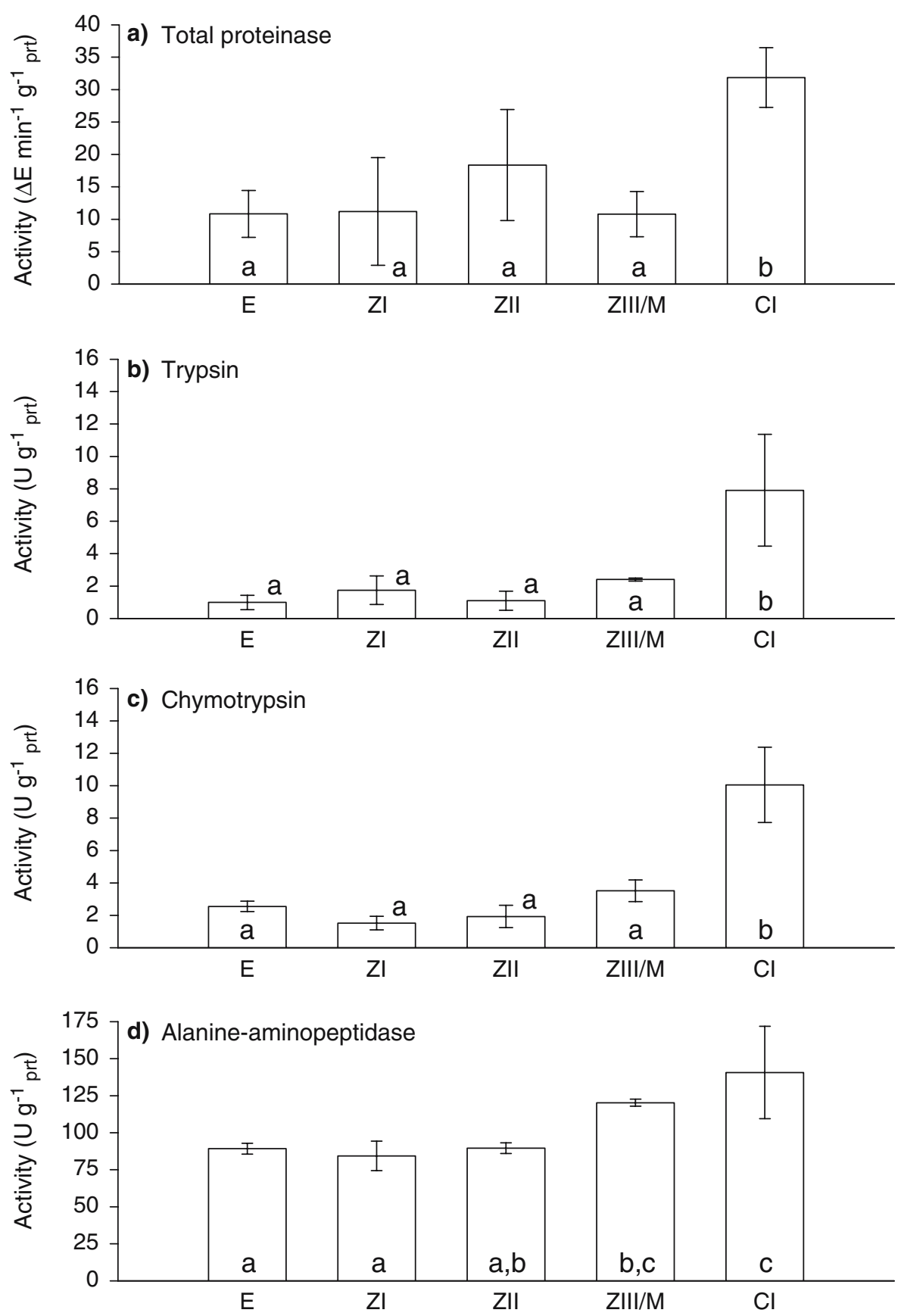

In the midgut gland tissues of later juveniles the relation between exopeptidase and endopeptidase was reversed (Fig. 3b), showing a sixfold higher activity of chymotrypsin than of alanine-aminopeptidase. The gastric fluid of adults even showed on average a 23 times higher activity of chymotrypsin.

\section{SDS-PAGE}

The proteinograms showed seven distinct protein bands between 59 and $81 \mathrm{kDa}$ in the early developmental stages (Fig. 4). The protein bands were most pronounced in the eggs and ZI, while they appeared weaker in the subsequent stages ZIII to CI. Four bands with $59,66,78$, and $81 \mathrm{kDa}$ disappeared in the CI stage.

\section{Endopeptidase zymograms}

The endopeptidase zymograms showed in eggs, ZI, ZII, and ZIII/M stages only weak activity bands of low molecular weights (apparently $15 \mathrm{kDa}$, Fig. 5). In the CI stage, the number of activity bands increased only slightly. In contrast, endopeptidases in the gastric fluid 

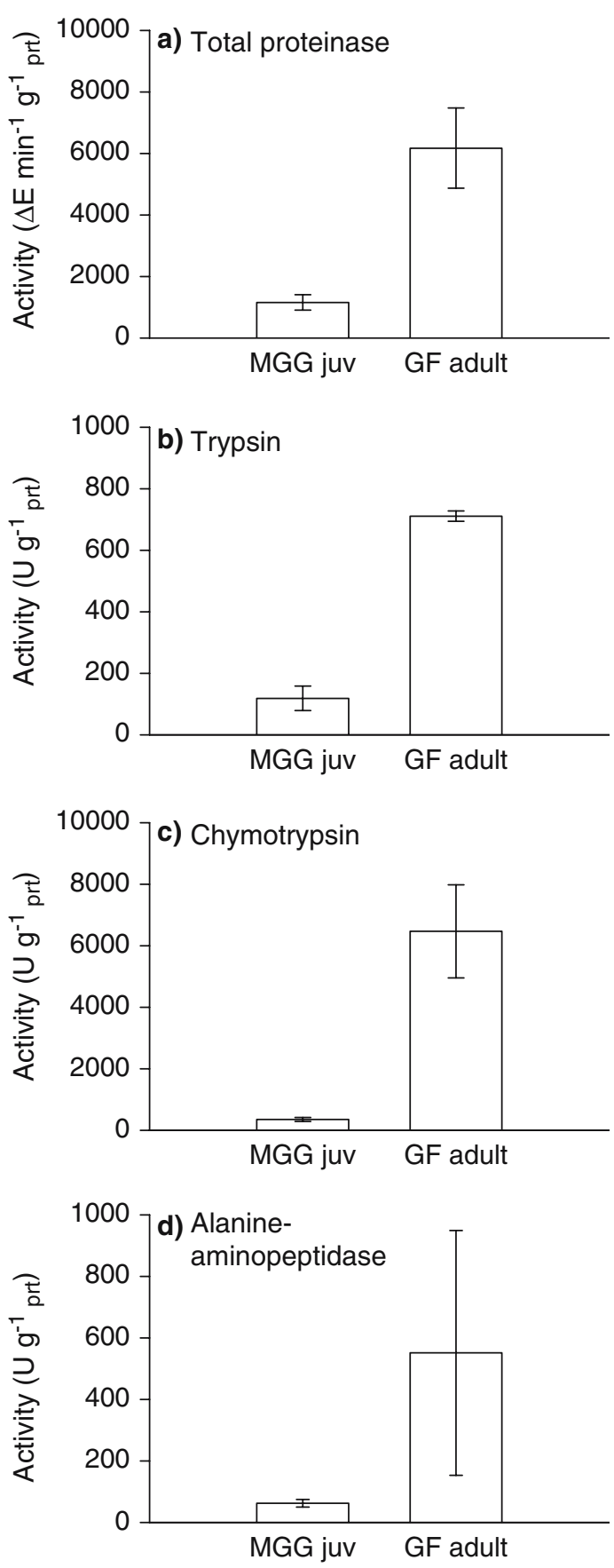

Fig. 2 Enzyme activities of midgut gland extracts of juvenile L. santolla (MGG juv) and of gastric fluids from adult $L$. santolla (GF adult) (means $\pm \mathrm{SD}, n=4-7$ ).

of adults showed distinct activity bands of apparently $12-20 \mathrm{kDa}$.

\section{Discussion}

Endopeptidases, or proteinases, such as trypsin and chymotrypsin are typical digestive enzymes, which have been detected in several crustacean species (e.g. Le Moullac et al. 1996; Jones et al. 1997; Kumlu and Jones
1997; Le Vay et al. 2001). They appear at high activities in the midgut gland and, particularly, in the stomach where they facilitate the extra-cellular cleavage of alimentary proteins (Dall and Moriarty 1983 and literature cited therein). Although the eggs and the larvae of L. santolla showed a certain level of total proteolytic activity, there was a marked deficiency of trypsin and chymotrypsin in all larval stages. A significant increase of both enzymes appeared for the first time in the first juvenile crab stage CI. ApiZym enzyme screening confirmed that trypsin activity increased continuously throughout development. The lack of chymotrypsin detection by the ApiZym assay was already observed in previous studies and may be attributed to a general incompatibility between the substrate $N$-glutaryl-phenylalanine-2-naphthylamide and crustacean chymotrypsin. In contrast to endopeptidases the activities of exopeptidases such as leucine- and valine-arylamidase were well pronounced already in the eggs.

As shown in other invertebrate species as well as in vertebrates, lysosomal enzymes, phosphatases, and proteases are involved in yolk protein degradation (e.g. Fagotto 1995; Carnevali et al. 2001 and literature cited therein). Our results indicate on the one hand, that the larvae of $L$. santolla are not physiologically prepared to digest external food due to the lack of typical gastric endopeptidases. On the other hand, elevated activities of phosphatase, exopeptidase, and esterase lipase (C8) indicate that Lithodes embryos and larvae are well suited to metabolize endogenous yolk reserves.

SDS-PAGE showed a continuous decrease of proteins or proteids of $59-81 \mathrm{kDa}$ through the early developmental stages. This decrease most likely reflects the metabolic utilization of endogenous storage products, i.e. yolk. Vitellin, which is a major yolk component in crustacean eggs, shows native molecular masses between 300 and $600 \mathrm{kDa}$ (e.g. Tom et al. 1992; Serrano-Pinto et al. 2003; Chen et al. 2004). However, depending on species or the procedure of extraction, vitellin may disintegrate into subunits. Serrano-Pinto et al. (2003) found subunits in the range of $75-180 \mathrm{kDa}$ in crayfish and Chen et al. (2004) found two subunits of 97 and $74 \mathrm{kDa}$ in Chinese mitten-handed crabs after denaturing SDSPAGE. In our study we did not identify vitellin immunologically in eggs and larvae of L. santolla, but we assume that larvae catabolize endogeneous vitellin like yolk proteins which are similar to the yolk proteins from the eggs. This assumption is supported by identical electrophoretic protein patterns in the eggs and larval stages.

The amount of water-soluble protein increased from the egg to the ZI stage and thereafter continuously decreased with progressing larval development. Apparently, yolk proteins from the eggs were at hatching reconstituted or disintegrated into a metabolically better utilizable form to better meet the elevated energetic demands of the now mobile larvae. During their development, larvae of $L$. santolla metabolize $56-58 \%$ of their initial carbon and $20 \%$ of initial nitrogen (Lovrich et al. 

arylamidase and chymotrypsin in different stages, juvenile and in the gastric fluid of adult $L$. santolla: a $E$ eggs, $Z I$ zoea I, $Z I I$ zoea II, $Z I I I / M$ zoea III and megalopae, $C I$ crab I. b Juv juvenile (midgut gland), $G F$ gastric fluid of adults (means $\pm \mathrm{SD}, n=4-7$ )
Fig. 3 Activity ratios of alanin-

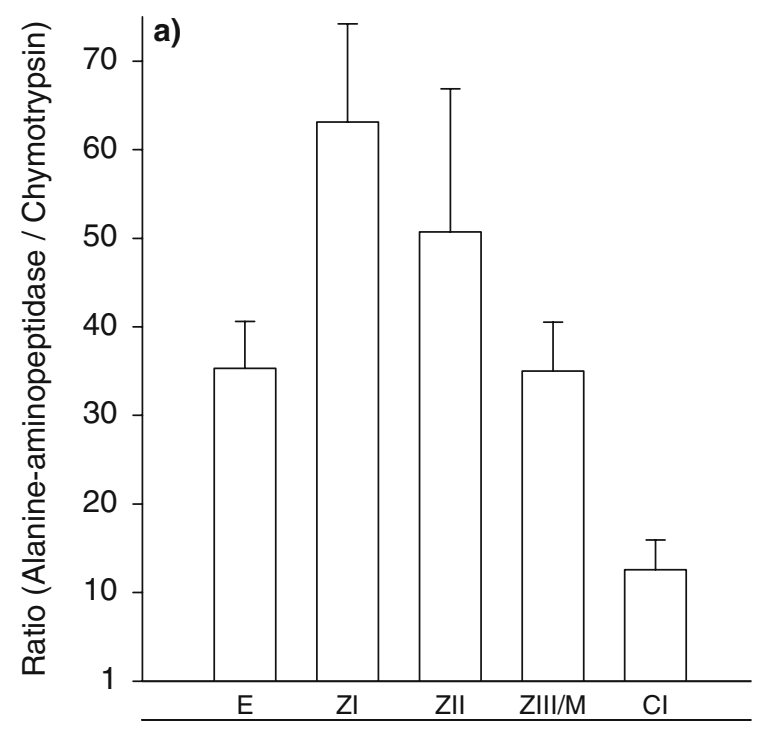

b)

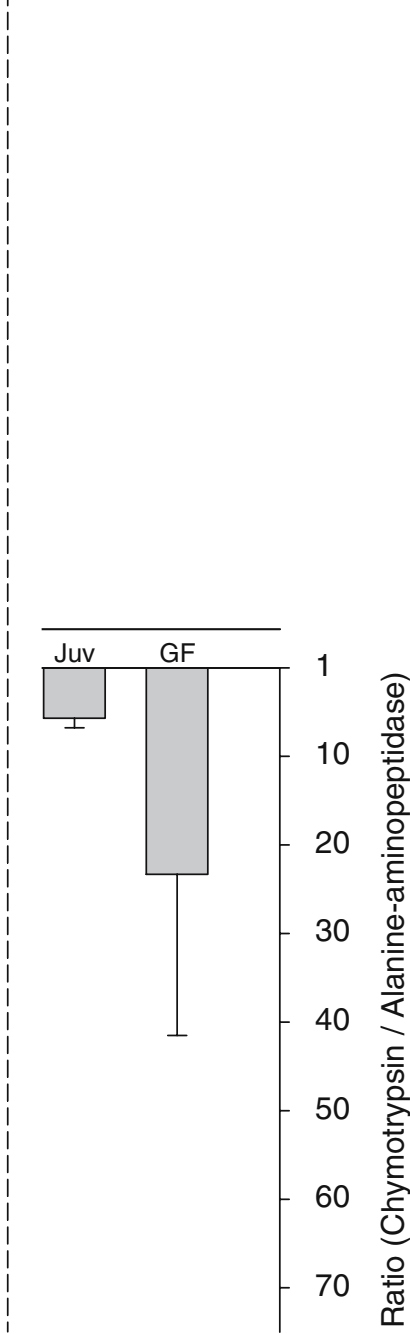

Fig. 4 SDS-PAGE of extracts from different developmental stages of $L$. santolla $(M$ markers, $E$ eggs, $Z I$ zoea I, ZII zoea II, $Z I I I / M$ zoea III and megalopa, $C I$ crab I). Their apparent molecular mass of the major protein bands is indicated. Samples were not heated prior to electrophoresis

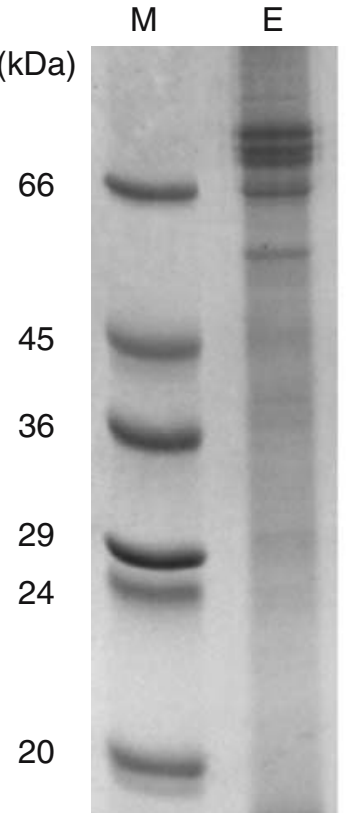

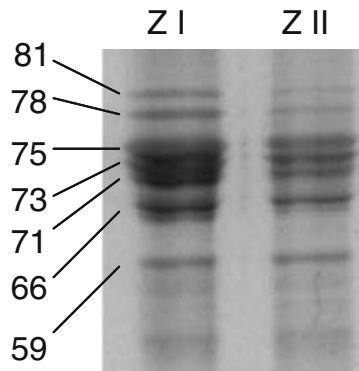

Z III/M

C I

M

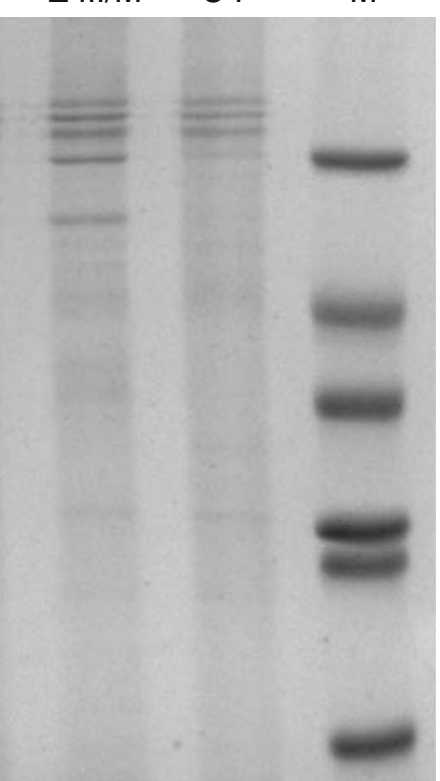


Fig. 5 Zymogram of endopeptidases of extracts from different developmental stages of $L$. santolla ( $E$ eggs, $Z I$ zoea I, $Z I I$ zoea II, $Z I I I / M$ zoea III and megalopae, CI crab I, Juv juvenile midgut gland, $G F$ gastric fluid from adults, $M$ markers). Activity bands are emphasized and their apparent molecular masses are indicated

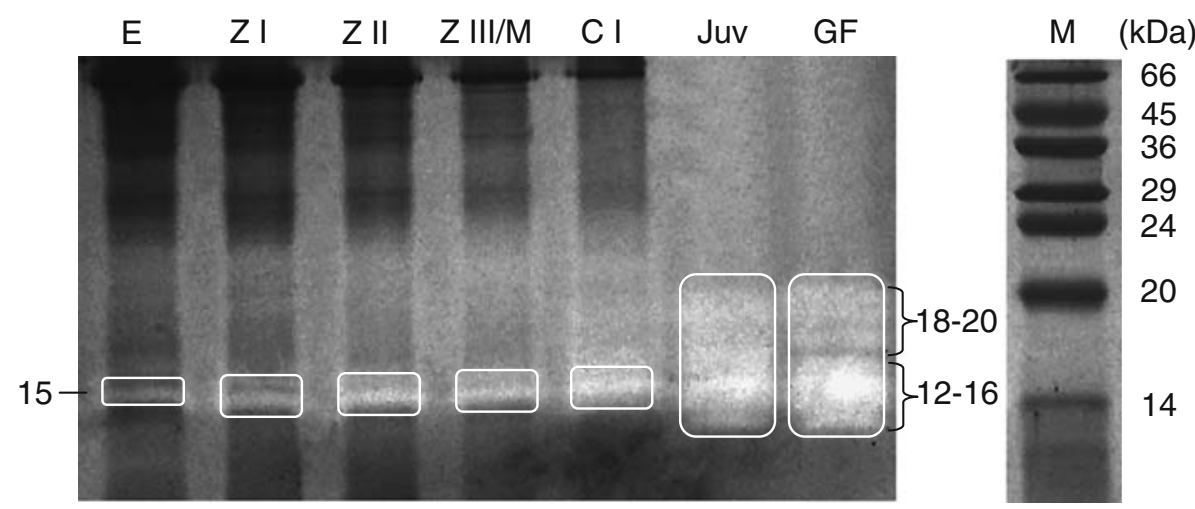

2003) assuming a predominant utilization of lipid and protein stores. The majority of total fatty acids $(46 \%)$ were utilized within the first 22 days after hatching, i.e. during the three zoea stages combined, while only another $15 \%$ were metabolized during the subsequent 40 days of development through the megalopa stage (Kattner et al. 2003).

Anatomical studies by McLaughlin et al. (2001) showed rudimentary mandibles, a retarded development of the maxillule, and setal reduction on the maxilla during the three zoeal stages. The authors attributed these features to lecithotrophy of the larvae of L. santolla. In other rearing experiments, Lovrich et al. (2003) and Calcagno et al. (2004) observed consistently the first uptake of food and beginning growth after metamorphosis to the first juvenile crab stage. Our results support these findings. The activities of the endopeptidases trypsin and chymotrypsin remained low during the larval stages but increased significantly at the CI stage. Moreover, the data show that the ratio between exo- and endopeptidases changed continuously during the development with an increasing proportion of endopeptidases. However, a significant increase of trypsin and chymotrypsin activity appeared first in the first juvenile crab stage, CI.

In contrast to our findings in the lecithotrophic lithodid larvae, studies on planktotrophic decapod larvae, e.g. those of penaeid shrimps, have demonstrated the appearance of endopeptidases in earlier ontogenetic stages (Fang and Lee 1992; Lemos et al. 1999, 2002). Only the eggs and the non-feeding nauplius stages lacked trypsin and chymotrypsin, while the activity of both enzymes peaked in the subsequent protozoeal stages. Among the decapods, penaeids show a particularly high number of larval stages. Accordingly, besides total proteinase activity also the iso-enzyme patterns of endopeptidases changed in response to variations in life style during ontogeny. In contrast, the larvae of L. santolla pass through only three zoeal stages. The uniformity of iso-enzymes expressed during the zoeal stages suggests uniformity in nutrition and probably in life style. The low activity and the low number of endopeptidase isoforms may indicate the absence of a functional midgut gland.
When grown to later juveniles and adults, L. santolla seems to be able to digest prey very efficiently. This became evident in the high activities of proteases and carbohydrases as determined with the ApiZym assay as well as in the high share of endopeptidases in the midgut glands of juveniles and the gastric fluids of adults. The total proteolytic activity in the gastric fluid of adult $L$. santolla was about twice as high as in the gastric fluid of the crab Cancer pagurus (Saborowski et al. 2004). Other Lithodes species are also known for their high digestive potential and stability of digestive enzymes. Galgani and Nagayama (1987) found in the midgut glands of five Lithodes species activities of trypsin, collagenase, and leucin-aminopeptidase.

L. santolla is a scavenger and predator, making use of dead organisms, e.g. fisheries discards. However, they feed also on the fauna of the benthic community in their habitats (Balzi 1997). The dominant prey species were other anomuran crabs, fishes, echinoids, and bivalves. Less frequent groups were stomatopods and squid (Comoglio and Amin 1996). The distribution of L. santolla is restricted to sub-polar regions with low water temperatures (Anger et al. 2004). Accordingly, L. santolla may have adapted to low temperatures, compensating for rate-limiting conditions by improving food utilization through elevated digestive enzyme activities.

In conclusion, our work showed that the eggs and larvae of the southern king crab, L. santolla, lacked endopeptidases. However, they exhibited high activities of exopeptidases, phosphatases, and esterase/lipase (C8). These enzymes seem to facilitate the intra-cellular utilization of yolk reserves. The activities of endopeptidases, which contribute to extra-cellular digestion, significantly increased in the first juvenile crab stage. Accordingly, the potential for utilization of external food appears in the first crab stage, which must, thus, be considered as the first feeding stage. Juvenile and adult $L$. santolla showed high activities of digestive enzymes in the midgut gland and in the gastric fluid, indicating an adaptation to low and, thus, rate limiting environmental temperatures as well as opportunistic utilization of scarcely appearing food. 
Acknowledgements We greatly appreciate the help of the crews of the RVs "Polarstern" and "Uthörn" during the transport of live crabs from South America to Helgoland and U. Nettelmann, G. Sahling, and S. Laakmann for help in the laboratory. This work was supported by the International Bureau of the German Federal Ministry of Education and Research (IB/BMBF project no. ARG 99/002) and the Argentine Secretaría de Ciencia, Technología e Inovación Productiva (SeCyT). The experiments comply with the current laws in Germany and Argentina.

\section{References}

Anger K (2001) The biology of decapod crustacean larvae. Crustacean issues 14. AA Balkema Publishers, Swets and Zeitlinger, Lisse, $420 \mathrm{pp}$

Anger K, Lovrich G, Thatje S, Calcagno J (2004) Larval and early juvenile development of Lithodes santolla (Molina, 1782) (Decapoda: Anomura: Lithodidae) reared at different temperatures in the laboratory. J Exp Mar Biol Ecol 306:217-230

Balzi PP (1997) Feeding habits of southern king crab, Lithodes santolla (Molina), in the San Jorge Gulf. Naturalia Patagonica Cienc Biol 5:67-87

Bradford M (1976) A rapid and sensitive method for the quantification of microgram quantities of protein utilizing the principle of protein-dye binding. Anal Biochem 72:248-254

Calcagno JA, Anger K, Lovrich GA, Thatje S, Kaffenberger A (2004) Larval development of the subantarctic king crabs Lithodes santolla and Paralomis granulosa reared in the laboratory. Helgol Mar Res 58:11-14

Carnevali O, Mosconi G, Cambi A, Ridolfi S, Zanuy S, PolzenettiMagni AM (2001) Changes of lysosomal enzyme activities in sea bass (Dicentrarchus labrax) eggs and developing embryos. Aquaculture 202:249-256

Chen L, Jiang H, Zhou Z, Li K, Li K, Deng GY, Liu Z (2004) Purification of vitellin from the ovary of Chinese mitten-handed crab (Eriocheir sinensis) and development of an antivitellin ELISA. Comp Biochem Physiol B 138:305-311

Comoglio L, Amin O (1996) Natural diet of the southern king crab Lithodes santolla in the Beagle Channel, Tierra del Fuego, Argentina. Biol Pesq 25:51-57

Dall W, Moriarty DJW (1983) Functional aspects of feeding and digestion. In: Mantel LH (ed) The biology of crustacea. Vol 5. Internal anatomy and physiological regulation. Academic, New York, pp 215-261

Dawson EW (1989) King crabs of the world (Crustacea: Lithodidae) and their fisheries: a comprehensive bibliography. Misc Publ, vol 101. New Zealand Oceanogr Inst, Div Water Sci, DSIR, Wellington

Fagotto F (1995) Regulation of yolk degradation, or how to make sleepy lysosomes. J Cell Sci 108:3645-3647

Fang LS, Lee BN (1992) Ontogenetic change of digestive enzymes in Penaeus monodon. Comp Biochem Physiol 103B:1033-1037

Galgani F, Nagayama F (1987) Digestive proteases in five species of Lithodidae (Crustacea, Decapoda). Comp Biochem Physiol B 87:103-107

Garçia-Carreño FL, Dimes LE, Haard NF (1993) Substrate-gel electrophoresis for composition and molecular weight of proteinases or proteinaceous proteinase inhibitors. Anal Biochem 214:65-69

Geiger R (1988) Chymotrypsin. In: Bergmeyer HU (ed) Methods of enzymatic analysis. 3rd edn, vol 5. Enzymes 3: peptidases, proteinases and their inhibitors. $\mathrm{VCH}$ Verlagsgesellschaft, Weinheim, pp 99-118

Geiger R, Fritz H (1988) Trypsin. In: Bergmeyer HU (ed) Methods of enzymatic analysis. 3rd edn, vol 5. Enzymes 3: peptidases, proteinases and their inhibitors. VCH Verlagsgesellschaft, Weinheim, pp 119-129
Hafkenscheid JCM (1988) Amino acid arylamidase. In: Bergmeyer HU (ed) Methods of enzymatic analysis. 3rd edn, vol 5. Enzymes 3: peptidases, proteinases and their inhibitors. $\mathrm{VCH}$ Verlagsgesellschaft, Weinheim, pp 11-15

Jones DA, Kumlu M, Le Vay L, Fletcher DJ (1997) The digestive physiology of herbivorous, omnivorous and carnivorous crustacean larvae: a review. Aquaculture 155:289-299

Kattner G, Graeve M, Calcagno JA, Lovrich GA, Thatje S, Anger K (2003) Lipid, fatty acid and protein utilization during lecithotrophic larval development of Lithodes santolla (Molina) and Paralomis granulosa (Jacquinot). J Exp Mar Biol Ecol 292:61-74

Kumlu M, Jones DA (1997) Digestive protease activity in planktonic crustaceans feeding at different trophic levels. J Mar Biol Assoc UK 77:159-165

Lemos D, Hernández-Cortés MP, Navarrete A, Garcia-Carreño FL, Phan VN (1999) Ontogenetic variation in digestive proteinase activity of larvae and postlarvae of the shrimp Farfantepenaeus paulensis (Crustacea: Decapoda: Penaeidae). Mar Biol 135:653-662

Lemos D, Garcia-Carreño FL, Hernández P, Navarrete del Toro MA (2002) Ontogenetic variation in digestive proteinase activity, RNA and DNA content of larval and postlarval white shrimp Litopenaeus schmitti. Aquaculture 214:363-380

Le Moullac G, Klein B, Sellos D, Van Wormhoudt A (1996) Adaptation of trypsin, chymotrypsin and $\alpha$-amylase to casein level and protein source in Penaeus vannamei (Crustacea Decapoda). J Exp Mar Biol Ecol 208:107-125

Le Vay L, Jones DA, Puello-Cruz AC, Sangha RS, Ngamphongsai C (2001) Digestion in relation to feeding strategies exhibited by crustacean larvae. Comp Biochem Physiol A 128:623-660

Lovrich GA, Thatje S, Calcagno JA, Anger K, Kaffenberger A (2003) Changes in biomass and chemical composition of the southern king crab, Lithodes santolla (Molina). J Exp Mar Biol Ecol 288:65-79

McLaughlin PA, Anger K, Kaffenberger A, Lovrich GA (2001) Megalopal and early juvenile development in Lithodes santolla (Molina, 1782) (Decapoda, Anomura; Paguroidea: Lithodidae), with notes on zoeal variations. Invertebr Reprod Dev 40:53-67

McLaughlin PA, Anger K, Kaffenberger A, Lovrich GA (2003) Larval and early juvenile development in Paralomis granulosa (Jacquinot) (Decapoda: Anomura: Paguroidea: Lithodidae), with emphasis on abdominal changes in megalopal and crab stages. J Nat Hist 37:1433-1452

Saborowski R, Sahling G, Navarrete del Toro MA, Walter I, García-Carreño FL (2004) Stability and effects of organic solvents on endopeptidases from the gastric fluid of the marine crab Cancer pagurus. J Mol Catal B Enzym 30:109-118

Serrano-Pinto V, Vazquez-Boucard C, Villarreal-Colmenares H (2003) Yolk proteins during ovary and egg development of mature female freshwater crayfish (Cherax quadricarinatus). Comp Biochem Physiol A 134:33-43

Thatje S, Anger K, Calcagno JA, Lovrich GA, Pörtner HO, Arntz WE (2005) Challenging the cold: crabs reconquer the Antarctic. Ecology 86(3):619-625

Thorson G (1936) The larval development, growth and metabolism of Arctic marine bottom invertebrates compared with those of other seas. Medd Grnland 100:1-155

Thorson G (1950) Reproductive and larval ecology of marine bottom invertebrates. Biol Rev 25:1-45

Tom M, Fingerman M, Hayes TK, Johnson V, Kerner B, Lubzens E (1992) A comparative study of the ovarian proteins from two penaeid shrimps, Penaeus semisulcatus (de Haan) and Penaeus vannamei (Bone). Comp Biochem Physiol B 102:483-490 